\title{
Potential heterogeneity in crustacean zooplankton assemblages in southern chilean saline lakes
}

\author{
De los Rios-Escalante, $P^{a *}$ and Gajardo, G. ${ }^{b}$ \\ aLaboratorio de Limnología, Facultad de Recursos Naturales, Escuela de Ciencias Ambientales, \\ Universidad Católica de Temuco, Casilla 15-D, Temuco, Chile

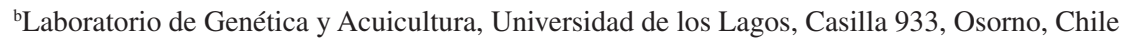 \\ *e-mail: prios@uct.cl \\ Received October 5, 2009 - Accepted February 23, 2010 - Distributed November 30, 2010
}

\begin{abstract}
The Chilean saline lakes are distributed mainly in the Atacama desert in northern Chile and the southern Patagonian plains. The scarce studies are restricted mainly to northern Chilean saline lakes, and these revealed that the main component in these ecosystems are the halophylic copepod Boeckella poopoensis Marsh 1906, or the brine shrimp Artemia franciscana (Kellog, 1906), and both species do not coexist. The present study consisted of field observations in zooplankton assemblages in southern Chilean saline lakes $\left(51-53^{\circ} \mathrm{S}\right)$. These first observations revealed three different patterns, one saline lake only with A. persimilis (Piccinelli and Prosdocimi, 1968), a second lake only with B. poopensis, and a third lake with $A$. persimilis, B. poopoensis and unidentified harpacticoid copepod. These results are different in comparison with the observations in the literature that described the non-coexistence between B. poopoensis with brine shrimps. Ecological and biogeographical topics were discussed.
\end{abstract}

Keywords: Boeckella poopoensis, Artemia, saline lakes.

\section{Heterogeneidade potencial em associações crustáceas do zooplâncton em lagos salinos chilenos do sul}

\begin{abstract}
Resumo
Os lagos salinos chilenos são distribuídos principalmente no deserto de Atacama no Chile do norte e em planícies do sul da Patagônia. Os estudos escassos são restringidos principalmente aos lagos salinos chilenos do norte, e estes revelaram que o componente principal nestes ecossistemas é halophylic copepod Boeckella poopoensis Marsh 1906 ou o camarão de salmoura Artemia franciscana (Kellog, 1906), e ambas as espécies não coexistem. O estudo atual consistiu em observações do campo em reuniões do zooplâncton nos lagos salinos chilenos do sul (51-53 $\left.{ }^{\circ} \mathrm{S}\right)$. Estas primeiras observações revelaram três testes padrões diferentes: um lago salino somente com Artemia persimilis, Piccinelli \& Prosdocimi, 1968; um segundo lago somente com B. poopoensis; e um terceiro lago com A. persimilis, B. poopoensis e o não identificado harpacticoid copepod. Estes resultados são diferentes em comparação com as observações da literatura que descreveram a não coexistência entre o B. poopoensis com camarões de salmoura. Os tópicos ecológicos e biogeográficos foram discutidos.
\end{abstract}

Palavras-chave: Boeckella poopoensis, Artemia, lagos salinos.

Chile is a sort of bio-geographical island isolated by the Pacific Ocean (West), the Andes Mountains (East), Glaciers in the extreme south, and the Atacama Desert in the north, one of the driest in the world. It stretches from latitude $30^{\circ}$ south to $52^{\circ}$ south with salty lakes at both ends with rather contrasting weather conditions, a somewhat unusual situation as salty lakes tend to be located mostly in tropical and subtropical areas (Van Stappen, 2003). The southern Chilean Patagonia has a semiarid climate and the numerous shallow water bodies found in the area exhibit a wide salinity gradient caused mainly by high evaporation rates due to extremely windy conditions (Gajardo et al., 1998), hence zooplankton assemblages vary in species richness according to the lake sampled. Here we report the salinity, conductivity and zooplankton composition of three lakes located in protected areas of the administrative Magallanes region (51-54 S): 1) Amarga lagoon ("bitter" lagoon; 50 $29^{\prime} \mathrm{S} / 72^{\circ} 45^{\prime} \mathrm{W} ; 3 \mathrm{~m}$ maximum depth) at the entrance of Torres del Paine National Park, the first saline lake reported for southern Chile (Gajardo et al., 1998); 2) Ana lagoon (52 $04^{\prime} \mathrm{S}$ and $69^{\circ} 47^{\prime} \mathrm{W} ;<2 \mathrm{~m}$ maximum depth) in Pali Aike National Park, an arid plain close to the Argentinean border; and 3) De los Cisnes lagoon (53 $14^{\circ} \mathrm{S}$ and $70^{\circ} 00^{\prime} \mathrm{W} ; 3 \mathrm{~m}$ maximum depth), a saline lake located in Tierra del Fuego island. These sites were visited in January 2008, zooplankton samples were collected using horizontal hauls with a plankton net of $20 \mathrm{~cm}$ diameter and $80 \mu \mathrm{m}$ mesh size, the specimens were fixed with absolute ethanol for identification according to previous reports (Bayly, 1992; Gajardo et al., 1998). 
Conductivity and salinity were measured in situ using a YSI-30 sensor.

Results revealed that Amarga lagoon parallels conditions to salty lakes in northern Chile (Gajardo et al., 1998) as it shows high salinity and conductivity $(105.0 \mathrm{~g} / \mathrm{L}$; $111.2 \mathrm{mS} / \mathrm{cm}$ ) with only the presence of $A$. persimilis. Nevertheless, the fact that a different species, A. persimilis, is found in Amarga lagoon, whilst A. franciscana is exclusively observed in the Atacama Desert in northern Chile, suggests that both habitats are either ecological barriers for the survival of both species, or other conditions (latitude, temperature) act as a geographical barrier between them. Although Ana lagoon tends to be similar in salinity $(79.6 \mathrm{~g} / \mathrm{L})$ and conductivity $(96.5 \mathrm{mS} / \mathrm{cm})$ levels to Amarga lagoon, only the copepod Boeckella poopoensis (Marsh, 1906) was found, whilst in De los Cisnes lagoon both $A$. persmilis, $B$. poopoensis and harpacticoids copepods were found, though this site has low salinity (45.2 g/L) and conductivity $(67.2 \mathrm{mS} / \mathrm{cm})$ in comparison with the other three sites. The presence of cladocerans and rotifers was not observed, a similar situation reported for saline lakes of the South American Altiplano (De los Rios, 2005; De los Rios and Gajardo, 2010).

One important result is the presence together of the halophylic copepod B. poopoensis and Artemia in De Los Cisnes lagoon at the time of collection, something unexpected (Hurlbert et al., 1986), though a similar finding of non coexistence was reported for shallow saline lakes in central Argentina (Echaniz et al., 2006; Vignatti et al. 2007) and Altiplano (De los Rios and Gajardo, 2010). As supposed by Hurlbert et al. (1986) Artemia and halophylic copepods (in example $B$. poopoensis) would not coexist because copepods would predate Artemia nauplius. Regarding this point, we do not know if this predation ability is associated to $A$. franciscana exclusively, whilst this could not be the case for A. persimilis. The obtained results denoted that more ecological studies of zooplankton assemblages in southern Patagonian shallow ponds are necessary, considering that these ecosystems are exposed to climate changes that are associated with drying periods that would affect its salinity and as a consequence, the aquatic communities (De los Ríos, 2005).
Acknowledgements - This study was financed by the Environmental Sciences School and Research General Direction (Grant for Development of Limnology Project DCAUCT-2007-01) of the Catholic University of Temuco. We express our gratitude to the personnel of the National Forestal Corporation of Torres del Paine and Pali-Aike National Parks and De los Cisnes Natural Monument for access facilities to the respective protected areas.

\section{References}

BAYLY, IAE., 1992. Fusion of the genera Boeckella and Pseudoboeckella and a revision of their species from South America and subantarctic islands. Revista Chilena de Historia Natural, vol. 65, no. 1, p. 17-63.

DE LOS RIOS, P. and GAJARDO, G., 2010. A null model to explain zooplankton species associations in saline lakes of the South American Altiplano. Crustaceana, vol 83, no 7, p. 769-777.

DE LOS RÍOS, P., 2005. Richness and distribution of zooplanktonic crustacean species in Chilean altiplanic and southern Patagonia ponds. Polish Journal Environmental Studies, vol. 14, no. 6, p. 817-822.

ECHANIZ, SA., VIGNATTI, AM., DE PAGGI, SJ., PAGGI, JC. and PILATI, A., 2006. Zooplankton seasonal abundance of South American saline shallow lakes. International Revue ges Hydrobiologie, vol. 91, no. 1, p. 86-100.

GAJARDO, GM., COLIHUEQUE, N., PARRAGUEZ, M. and SORGELOOS, P., 1998. International study on Artemia VIII. Morphologic differentiation and reproductive isolation of Artemia populations from South America. International Journal Salt Lake Research, vol. 7, no. 2, p. 133-151.

HURLBERT, SH., LOAYZA, W. and MORENO, T., 1986. Fishflamingo-plankton interactions in the Peruvian Andes. Limnology and Oceanography, vol. 31, no. 3, p. 457-468.

STAPPEN, G. van, 2003. Zoogeography. In DOOR, TH., ABATZOPOULOS, J. and BEARDMORE, JA. (Eds.). Artemia: basic and applied biology. Boca Ratón, Florida, USA: CRC Press Inc, p. 171-224.

VIGNATTI, A., ECHANIZ, S. and MARTÍN, MC., 2007. El zooplancton de tres lagos someros de diferente salinidad y estado trófico en la región semiárida pampeana (Argentina). Gayana, Zoología, vol. 71, no. 1, p. 34-48. 